\title{
Effect of Aqueous Ozone To Control Fungal Postharvest Diseases of Strawberry
}

Caroline Corrêa de Souza Coelho (II), Otniel FREITAS-SILVA (I), Rodrigo da Silveira Campos (I), Miguel da Silva Gomes Pereira (II), Lourdes Maria Corrêa Cabral (I)

(I) EMBRAPA - EMBRAPA Food Technology (Av. das Américas, 29501, Rio de Janeiro, RJ, CEP 23020-470), (II) UFRRJ - Universidade Federal Rural do Rio de Janeiro (BR 465, Km 7, Campus Universitário - Seropédica, Rio de Janeiro, RJ, 23851-970)

\section{Resumo}

The strawberry (Fragaria $\times$ ananassa Duch.) a small fruit crop of great importance in all around the world, has a high susceptibility to a large variety of phytopathogenic organisms, promoting considerable postharvest losses. Thus, the step of sanitizing becomes important process to maintain the quality of fruits. Predominant fungal postharvest diseases of strawberry are caused mainly by Botrytis cinerea, Rhizopus stolonifer, Colletotrichum gloeosporioides, Cladosporium sp. and Penicillium sp. This study aimed to evaluate and compare with chlorine the effectiveness of aqueous ozone to overcome in vitro and in vivo postharvest diseases of strawberry during cold storage. Concentrations of traditional chlorination (immersion in Sumaveg ${ }^{\circledR} 150 \mathrm{mg} / \mathrm{L}$ subsequent rinsing with $5 \mathrm{mg} / \mathrm{L}$ for 10 minutes) and aqueous ozone [ 0 (control), $0.2,0.5$, and $1.0 \mathrm{mg} / \mathrm{L}]$ were applied during 5 minutes in both trials, in vitro and in postharvest strawberries cv. Camino Real. The experimental design was completely randomized with three replications. Radial mycelia growth was evaluated after fungal exposure to the different aqueous chlorine and ozone treatments. Significant inhibition in radial mycelia growth of C. gloeosporioides, Penicillium sp., Cladosporium sp. and Botrytis cinerea was observed ( $\mathrm{p}<0.05)$, respectively, in all ozone treatments as compared to chlorination and control treatments until 6 days of incubation at $25 \pm 1^{\circ} \mathrm{C}$. In strawberries storage for 10 days at $5 \pm 2{ }^{\circ} \mathrm{C}$ and $80 \%$ relative humidity, the gray mold

\footnotetext{
Referência:

Caroline Corrêa de Souza Coelho, Otniel FREITAS-SILVA, Rodrigo da Silveira Campos, Miguel da Silva Gomes Pereira, Lourdes Maria Corrêa Cabral.Effect of Aqueous Ozone To Control Fungal Postharvest Diseases of Strawberry. In: Anais do $12^{\circ}$ Congresso Latinoamericano de Microbiologia e Higiene de Alimentos - MICROAL 2014 [= Blucher Food Science Proceedings, num.1, vol.1]. São Paulo: Editora Blucher, 2014. 
caused by Botrytis cinerea, was the disease with higher incidence, especially in fruits from chlorination treatment. Ozonation showed superior performance when compared to chlorination in reducing postharvest phytopathogens of strawberry, whereas the concentration of $0.5 \mathrm{mg} / \mathrm{L}$ for 5 minutes delayed and decreased the disease incidence in fruits. In view of it this concentration presents higher potential to be adopted in the sanitization process for strawberries cv. Camino Real.

Palavras-Chave: decay, Fragaria $\times$ ananassa, mycobiota, ozonation, postharvest

Agência de Fomento: Coordenação de Aperfeiçoamento de Pessoal de Nível Superior 